\title{
INSTRUCTIO, LIBERTAS E EXERCÍCIO DOCENTE NA CONTEMPORANEIDADE*
}

\author{
Claudio Almir Dalbosco ${ }^{1}$ (D)
}

\begin{abstract}
RESUMO: O ensaio argumentou a favor do papel formativo do professor, o qual desempenha, enquanto governante intelectual, papel indispensável na formação de novas geraçôes. Assim, o texto investigou, na primeira parte, diferentes formas de reducionismo da educação contemporânea, provocadas pela invasão da governança empresarial neoliberal nas instituiçôes de ensino, focando no empobrecimento da experiência docente. Reconstruiu, na segunda parte, alguns traços do perfil do mestre que emerge da noção latina de educação como instructio, concentrando-se no ideal da libertas como núcleo da relaçáo formativa entre mestre e discípulo, ou seja, entre educador e educando. Dessa breve reconstrução, procurou extrair alguns argumentos favoráveis ao papel formativo do professor em relação a si mesmo e aos seus alunos.
\end{abstract}

Palavras-chave: Formação. Instructio. Libertas. Professor. Aluno.

\section{INSTRUCTIO, LIBERTAS AND TEACHING IN THE CONTEMPORARY WORLD}

ABSTRACT: This essay argues in favor of the teacher's formative role, who, as an intellectual ruler, plays an indispensable role in the formation of new generations. First, the essay investigates different forms of reductionism of contemporary education, caused by the invasion of neoliberal corporate governance into educational institutions, and focuses on the impoverishment of the teaching experience. Then, the essay reconstructs some traits of the master's profile that emerges from the Latin notion of education as instructio, focusing on the ideal of libertas as the core of the formative relationship between master and disciple, that is, between educator and learner. This brief reconstruction seeks to extract some arguments favorable to the formative role of teachers in relation to themselves and their students.

Keywords: Education. Instructio. Libertas. Teacher. Student.

\footnotetext{
${ }^{*} \mathrm{O}$ ensaio vincula-se ao projeto de pesquisa Formação humana e exercício de si, financiado pelo Conselho Nacional de Desenvolvimento Científico e Tecnológico (CNPq) na modalidade de Bolsa de Produtividade em Pesquisa (PQ).

${ }^{1}$ Universidade de Passo Fundo, Programa de Pós-Graduação em Educação - Passo Fundo (RS), Brasil.

E-mail: vcdalbosco@hotmail.com
}

DOI: 10.1590/ES0101-73302019220333 


\title{
INSTRUCTIO, LIBERTAS Y EL EJERCICIO DOCENTE EN LA CONTEMPORANEIDAD
}

\begin{abstract}
RESUMEN: Este ensayo argumenta en favor del papel formativo del profesor, el cual desempeña, en cuanto gobernante intelectual, un papel indispensable en la formación de las nuevas generaciones. Así, se investiga, en la primera parte, diferentes formas de reduccionismos en la educación contemporánea, provocadas por la invasión de la gobernabilidad empresarial neoliberal en las instituciones educativas, direccionadas al empobrecimiento de la experiencia docente. En la segunda parte son reconstruidos algunos rasgos del perfil del maestro, que emergen de la noción latina sobre educación como instructio, centralizando en el ideal libertas, como foco de la relación formativa entre el maestro y el discípulo, o sea, entre educador y educando. A partir de esta breve reconstrucción, se pretende extraer algunos argumentos favorables al papel formativo del profesor en relación a sí mismo y a sus alumnos.
\end{abstract}

Palabras clave: Instructio. Libertas. Profesor. Alumno.

\section{Introdução}

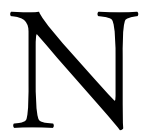

a tradição da cultura ocidental, desde a Antiguidade grega, a educação é compreendida como modo promissor de formação de si mesmo. Constituída de diferentes formas de exercício de si, implica, tanto na versão grega originária como na latina posterior, a relação entre educador e educando, efetivada por meio da relação entre mestre e discípulo. $\mathrm{Na}$ tradição grega, Sócrates é o grande mestre que ensina seus discípulos em praça pública, tomando como ponto de partida a vida cotidiana e o mundo existencial de seus interlocutores. Por meio de perguntas, busca conduzi-los ao autoexame de suas crenças e convicçôes, convencendo-os da importância de analisá-las permanentemente. De outra parte, na tradição latina, Sêneca é um dos principais mestres, que por intermédio de longas cartas dirigidas ao seu discípulo Lucílio, conduze-o a tomar consciência das intempéries da vida e dos problemas que o afligem, aconselhando-o sobre o modo mais adequado de enfrentá-los.

Apesar das enormes diferenças entre esses dois grandes e antigos modelos educacionais, há entre eles algumas características comuns:

- A educação é compreendida como modo de pensar sobre a vida e a existência dos envolvidos, e não somente como preparação para um ofício determinado. Isto é, por meio de muitos exercícios praticados diariamente, a educação é preparação, no sentido amplo do termo. Paraskeué é a versão grega, e instructio, a versão latina de educação; 
- Tanto no sentido grego como no latino de educaçáo, a relação entre mestre e discípulo é paradigmática. O mestre é alguém bem formado, que se torna educador experimentado após longos exercícios práticos e meditativos consigo mesmo e na companhia de outros seres humanos, com consciência virtuosa de seu lugar na ordem das coisas. O discípulo é aquele que se dispóe a ouvir o que o mestre tem a lhe dizer e, depois de ouvi-lo atentamente, o questiona-, visando formular suas próprias ideias e encontrar seu próprio caminho;

- Por fim, se a educação como preparação só ocorre na presença do outro como mestre, então sua figura se torna central e, por isso, deve ser constantemente problematizada. Quem é o mestre, qual é o seu perfil e quais são suas atribuiçōes constituem questôes decisivas da própria ideia e finalidade da educação antiga. Na tradição grega, tais questóes acerca do papel do mestre encontram-se sintetizadas pelo saber parresiástico, enquanto na tradição latina, sobretudo em Sêneca, elas estão reunidas no ideal da libertas.

Desse modo, parresia e libertas constituem duas grandes referências filosóficas e pedagógicas para pensar o sentido amplo da formação humana e, especialmente, a relação entre educador e educando. Enquanto referências, essas duas noçóes, simultaneamente, póem à luz a dimensão formativa da relação entre educador e educando, destacando a centralidade do trabalho do educador como formador das novas gerações.

$\mathrm{Na}$ modernidade, com o esforço iluminista de universalização da educação escolar, ocorreram profundas transformaçóes nos conceitos de educação e escola, fazendo com que a antiga relação mestre-discípulo fosse substituída pela relaçáo professor-aluno. Mesmo que houvesse esforços teóricos consistentes de atualização dos ideais educacionais e escolares antigos, tanto educação como escola se deixaram dominar progressivamente por forças sociais, econômicas e culturais externas. Considerando o nascente capitalismo industrial, o sentido da educação restringiu-se, aos poucos, à preparação do aluno para determinado ofício. Nesse contexto, por exemplo, a finalidade maior do currículo da educação escolar consistia, antes de tudo, na preparaçáo dos alunos para o exercício de determinadas profissóes, úteis às demandas do mercado de trabalho. $\mathrm{O}$ professor, focado no desenvolvimento de competências e habilidades dos alunos que interessavam diretamente ao mercado, distanciava-se cada vez mais da figura paradigmática do mestre antigo. Ou seja, a profissionalizaçáo do ofício de ensinar provocou, desde o começo da modernidade, o empobrecimento crescente do modo de ser professor, deixando-o cada vez mais longe da figura do mestre.

Vincent, Lahire e Thin (2001, p. 7-47) mostram como a forma escolar se tornou mais e mais dominante já no início da modernidade europeia, sobretu- 
do a partir do século XVII, transformando-se em núcleo referencial importante de socialização dos indivíduos e estendendo-se muito além do universo escolar propriamente dito, de modo a atravessar inúmeras instituiçóes e grupos sociais. A socialização escolar também deu origem a um formato inédito de relação pedagógica entre mestre e aluno. $\mathrm{O}$ ineditismo dessa relação caracterizava-se, segundo os referidos autores, pela sua independência de outras formas de relação social, fundando a escola como lugar singular de ensino e aprendizagem que exigia um tempo escolar específico, simultaneamente, "como período da vida, como tempo no ano e como emprego do tempo cotidiano" (VINCENT; LAHIRE; THIN, 2001, p. 13). Foi nessa singularidade da forma escolar que se radicou a profissionalização crescente do trabalho pedagógico do professor e que, também, o tornou membro intrínseco, assim como a própria instituição escolar, das modernas relaçôes sociais capitalistas.

Cabe ressaltar, para o momento, que o sentido reduzido de educação escolar, com o respectivo empobrecimento da experiência do professor, só tendeu a crescer na sociedade contemporânea, dominada pelo neoliberalismo. No contexto da sociedade neoliberal contemporânea, a educação diluiu-se, como atestou recentemente Gert Biesta (2013; 2017), em diferentes formas de aprendizagem, e a própria escola transformou-se, segundo diagnóstico acertado de Christian Laval (2004), em empresa, seguindo os princípios da governança empresarial. A noção de aprendizagem só consegue atender às finalidades da governança neoliberal, baseadas nos critérios da competiçáo, eficiência e rentabilidade, ao preço de ter de abandonar a ideia de educação como ampla preparação para a vida em comum. Essa demanda só é alcançada quando o foco é, exclusivamente, o desenvolvimento de competências e habilidades que auxiliam o indivíduo a tornar-se um empreender individualista de si mesmo. A educação escolar, teleguiada pela noçáo de aprendizagem, afasta-se do ideal de escola como tempo livre, deixando-se reduzir, cada vez mais, à finalidade do tempo produtivo, orientado pela modelagem do gerenciador empresarial individualista, que visa à rentabilidade econômica acima de tudo. Nesse contexto, o professor deixa de ser o guia espiritual dos alunos, cuja tarefa consistia em provocá-los a pensar sobre sua própria experiência existencial e sua posiçâa na ordem das coisas. $\mathrm{Na}$ contramáo disso, ele torna-se um expert, assumindo o papel de mediador da aquisição de conhecimentos e informaçóes considerados indispensáveis para que os alunos desenvolvam novas competências e habilidades úteis às necessidades mercadológicas da economia neoliberal (MASSCHELEIN; SIMONS, 2013).

Tal diagnóstico, resumido, mostra o empobrecimento crescente da experiência de ser professor, distanciando-o progressivamente de ideais educacionais cuja finalidade é a ampla formação cultural não só de seus alunos, mas dele próprio. Nossa hipótese, no presente ensaio, consiste em afirmar que é a condição de governante formador que torna irrenunciável a figura do professor, mostrando, ao 
mesmo tempo, a indispensabilidade da experiência escolar na educação das novas geraçóes. Contudo, para que o professor exerça o governo formativo e a escola possa de fato fazer a diferença na vida de seus alunos, tanto um como o outro, escola e professor, precisam manter certa autonomia em relação às demandas externas, as quais vêm normalmente expressas pelo tripé mercado, Estado e família. Isso significa dizer, em outros termos, que é preciso assegurar o tempo livre ao ambiente escolar, impedindo que ele seja dominado autoritariamente pelas forças desse tripé, pois é na sala de aula, concebida como espaço de acontecência do tempo livre, que professor e aluno exercitam o ócio estudioso, indispensável à construção de formas éticas, autônomas e solidárias de vida.

Pretendemos justificar nossa hipótese concentrando-nos, na primeira parte do ensaio, no aprofundamento do diagnóstico que póe em risco de maneira cada vez mais acentuada o papel formativo do professor. Entre as várias razóes que empobrecem a educação escolar, dificultando o papel de governante formador do professor, analisamos de modo breve três razóes, cada uma delas relacionadas respectivamente ao tripé mercado, Estado e família. Na segunda parte, reconstruímos alguns traços do perfil do mestre que emergem da noção latina de educação como instructio, concentrando-nos no ideal de libertas como núcleo da relação formativa entre mestre e discípulo, ou seja, entre educador e educando. Dessa concisa reconstruçáo, procuramos extrair alguns argumentos favoráveis ao papel formativo do professor no que se refere a si mesmo e aos seus alunos.

\section{Escola como empresa e professor como expert}

Inúmeras pesquisas empíricas mostram o estado de fadiga e indisposição dos professores na atualidade. Alguns autores chegam mesmo a falar de um mal-estar que domina a profissão docente, acompanhado de várias doenças psíquicas, entre elas, principalmente, a depressão ${ }^{1}$. As diferentes formas de empobrecimento da experiência docente conduzem à perda de centralidade do professor no contexto da sala de aula, tornando-o figura inexpressiva da educação escolar. Contudo, se o mestre era uma figura vital para a formação humana pretendida pelos antigos, o professor tornou-se, desde muito cedo, na modernidade, a figura de proa, sem a qual não haveria formação ampla nem consistente dos alunos. $\mathrm{Na}$ tradição pedagógica e filosófica alemã, por exemplo, tanto Immanuel Kant como Johann Friedrich Herbart destacam, cada um a seu modo, o trabalho indispensável do professor como diretor intelectual, na formação das novas gerações ${ }^{2}$. Quais foram, então, as razóes que levaram, num lapso de tempo menor que dois séculos, ao enfraquecimento da centralidade da figura do professor e o conduziram, por conseguinte, ao seu desprestígio social e cultural? Nessa primeira parte de nosso ensaio procuramos tratar dessa questão, concentrando-nos apenas em 
algumas das muitas razóes que justificam o enfraquecimento crescente do papel formativo do professor.

As instituiçóes formais de ensino, entre elas a escola e a universidade, não são uma ilha isolada da sociedade, como se pudessem existir em total independência do que acontece fora de seus muros. $\mathrm{O}$ que ocorre na sociedade entra, de uma forma ou de outra, dentro das instituições formais de ensino, caracterizando a invasão econômica, jurídica e política agressiva que procura curvar os agentes escolares e universitários aos ditames da nova ordem neoliberal. Se escola e universidade náo estáo imunes à sociedade, sendo influenciadas pelas suas tensóes e por seus conflitos, isso também interfere no exercício docente do professor. As forças externas assujeitam o professor quando querem determinar autoritariamente seu trabalho como educador, ditando-lhe o que deve ou năo ensinar e como fazê-lo. É assim, por exemplo, que mercado, Estado e família, cujos propósitos se estreitam entre si em determinada conjuntura social e política, fixam autoritariamente finalidades externas às instituiçóes formais de ensino, ignorando simplesmente sua autonomia e negando à sala de aula o tempo livre indispensável para que professor e aluno possam exercitar o ócio estudioso.

No capitalismo moderno, o mercado tornou-se força social, política e cultural dominante. O liberalismo clássico instituiu o credo de que a sociedade não pode existir sem o mercado, uma vez que este se torna a principal força de organização daquela. Como o mercado regula as amplas forças sociais, deve controlar também o Estado, as instituições formais de ensino, o modo de ser do professor e, em sentido mais amplo, a própria vida dos indivíduos. Na versão liberal clássica, o mercado é a grande mão invisível que regula os interesses sociais e individuais, regrando o egoísmo individual e a concorrência econômica entre as empresas.

Na segunda metade do século XX, como atestam os cursos de Michel Foucault ministrados no Collège de France, sobretudo o curso de 1978-1979 (FOUCAULT, 2008), o mercado assumiu a forma neoliberal, exigindo tanto a reconfiguração do Estado e das instituiçóes formais de ensino como a produção de novas subjetividades, desenvolvendo com isso novas formas de assujeitamento do ser humano. Nesse contexto, o mercado neoliberal instituiu a governança empresarial como novo modo de ser do capitalismo contemporâneo, impondo a toda a sociedade os princípios de competição, eficiência e rentabilidade econômica. Com base em tais princípios, não só as instituições como também os próprios sujeitos sofreram profundas modificaçōes, as quais vêm sintetizadas pela noção neoliberal do sujeito como empreendedor de si mesmo.

A governança empresarial provocou, primeiramente, profunda reestruturação do Estado, a qual terminou por afetar também a própria noção do público, em geral, e da escola pública, particularmente. O modelo do Estado social, 
que assegura direitos fundamentais aos cidadãos e provê serviços básicos como educação, saúde, moradia e transporte a todos, cedeu lugar ao Estado gerencial, regido pela lógica empresarial, baseada nos mesmos princípios indicados, ou seja, na competição, eficiência e rentabilidade. Nesse novo contexto, a noção de público deixou de se referir à noção de Estado como obrigação jurídica de assegurar os direitos sociais a todos os cidadãos e como instância reguladora do funcionamento da economia privada. O novo sentido de público foi na direção exatamente oposta, desobrigando juridicamente o Estado de seu papel social e transformando-o em agente empresarial. Com isso, ele deveria assumir as mesmas formas de gerenciamento que orientavam o modo de ser da economia neoliberal. Em síntese, a destruição do Estado social em nome do Estado gerencial tornou possível a importação das regras de funcionamento do mercado concorrencial para o setor público, adotando a concorrência como instrumento exclusivo para tornar eficiente a própria ação pública. A mudança de fundo tornou-se aí visível: experiências de cooperação solidária, que ainda eram possíveis no Estado social, foram simplesmente destruídas pelos novos dispositivos neoliberais de concorrência, eficiência e rentabilidade e de orientação marcadamente individualista.

Foi nesse âmbito mais amplo da transformação do Estado em grande empresa que o sentido público de educação se viu duramente ameaçado. De bem público inquestionável, voltada para a formação humana e cidadã, a educação transformou-se aos poucos em grande negócio lucrativo, administrado pelos mesmos princípios da governança empresarial. Ocorreu, então, resumidamente, a mercantilização crescente da educação, culminando na própria transformação da escola em empresa, ou seja, em lugar a ser gerenciado pelo mesmo tempo produtivo que orientava a lógica do gerenciamento empresarial. Com isso, a estrutura escolar sofreu grandes alteraçóes, fazendo com que, por exemplo, currículo, matéria e procedimentos de ensino se voltassem cada vez mais para o atendimento dos interesses impostos pelo mercado via mudança na legislação educacional, sustentada por novas políticas educativas governamentais.

À medida que essas grandes modificaçóes sociais e educacionais geradas pelo neoliberalismo provocavam o enfraquecimento brutal de experiências democráticas de cooperação solidária, elas abriam o flanco, simultaneamente, para a retomada de práticas autoritárias, baseadas em valores tradicionais de família. No caso específico da sociedade brasileira, as pequenas conquistas democráticas e sociais recentes, que tornaram possível o debate público sobre temas centrais da sociedade plural, ficam cada vez mais ameaçadas pela perspectiva conservadora autoritária em curso, ancorada na noção religiosa tradicional de família. Há, nesse sentido, por exemplo, a confluência entre o caráter autoritário subjacente à governança empresarial, tendo em vista que tenta impor seus princípios para toda a sociedade, e o sentido autoritário inerente à reinvindicação descabida de certos pais de quererem impor à escola e ao professor o que seus filhos devem aprender ${ }^{3}$. 
A mesma autonomia que o mercado pretende tirar da escola, ao transformá-la em empresa, também é negada, sob outra perspectiva, pelo exercício autoritário do poder disciplinador dos pais, os quais se arrogam no direito de determinar o modo de ser não só de seus filhos como também dos professores que os ensinam. O fato é que tanto num como no outro caso, a escola tornou-se braço da sociedade neoliberal, distanciando-se cada vez mais do ideal do tempo livre destinado ao exercício do ócio estudioso, no qual professor e aluno se exercitam reciprocamente, reinventando-se como sujeitos humanos. No fundo, o liberalismo econômico e o conservadorismo nos costumes terminam por coibir a liberdade individual e, sobretudo, as experiências de cooperação social, como núcleo indispensável da formação humana.

Como essas macrotransformaçóes se traduzem em formas de vida do sujeito contemporâneo e que influência exercem, especificamente, no modo de ser professor? Do ponto de vista intelectual, as contribuiçóes tardias de Foucault são decisivas, porque rompem com a posição determinista de que o sujeito contemporâneo é mero reflexo das diferentes formas de governança empresarial. Suas análises do neoliberalismo, aliadas aos estudos posteriores sobre a formação ética do sujeito na cultura antiga, greco-romana, concebem a liberdade humana como núcleo constitutivo das resistências que se contrapóem às diferentes formas de assujeitamento derivadas dos dispositivos próprios à governança empresarial. Isso se refere, do ponto de vista teórico, ao intrincado e difícil problema do entrelaçamento tensional entre subjetividades humanas e estrutura social e, por conseguinte, à questão educacional clássica da formação social de si mesmo. É no âmbito de tal tensão que a educação precisa ser pensada para além da aprendizagem, permitindo retomar a noção de escola como tempo livre e, nesse contexto, do próprio papel formativo do professor. Ou seja, é a noção de educação como instrução e não como mera aprendizagem que abre frestas conceituais para pensar a figura insubstituível do professor como governante intelectual do processo formativo que ocorre no interior da escola, especificamente dentro da sala de aula.

O problema teórico indicado auxilia a ver com mais precisão a influência dessas macrotransformações na constituição do sujeito contemporâneo. Muitos estudos no campo da psicanálise têm indicado o quanto a nova ordem mundial neoliberal produz novas formas de vida entrelaçadas, em certo sentido, com uma nova psique humana ${ }^{4}$. Ou seja, somente um novo sujeito é capaz de viver de acordo com a governança empresarial, legitimando-a ao assumir seus dispositivos. Esse novo sujeito é denominado de empreendedor individualista de si mesmo. Por meio de permanentes processos de subjetivação, tal sujeito internaliza os princípios que regem o gerenciamento empresarial recriando-o. Isso significa dizer que, para poder ser bem-sucedido, o sujeito precisa transformar-se ele mesmo em uma pequena empresa. É desse modo que os dispositivos gerais do 
governo empresarial se transformam, do ponto de vista da formação do sujeito neoliberal, na gestão das mentes individuais. Disso resultam atributos específicos do sujeito empreendedor de si mesmo: é um sujeito ativo, que deve participar inteiramente, engajar-se plenamente, entregando-se por completo à sua atividade profissional. Como afirmam Dardot e Laval (2016, p. 331): "Especialista em si mesmo, empregador de si mesmo, investidor de si mesmo, inventor de si mesmo, empreendedor de si mesmo: a racionalidade neoliberal impele o eu a agir sobre si mesmo para fortalecer-se e, assim, sobreviver na competição". Observa-se, com isso, que todas essas características atribuídas ao sujeito contemporâneo repousam na ideia da competição tomada como essência da governança empresarial neoliberal. Desse modo, a busca cooperativa do reconhecimento social dá lugar à concorrência desenfreada, na qual cada um busca ser superior ao outro, a qualquer custo 5 .

Qual é o significado dessa transformação do sujeito contemporâneo em empreendedor de si mesmo para o modo de ser professor? É preciso considerar, antes de tudo, a transformação mais ampla que ocorre na escola, à medida que ela assume o modus operandi do gerenciamento empresarial. Como afirma Laval (2004, p. XI): "A escola neoliberal designa um certo modelo escolar que considera a educação como um bem essencialmente privado e cujo valor é, antes de tudo, econômico". Considerando isso, é essa transformação que materializa a possibilidade de o professor tornar-se empreendedor de si mesmo. Ao ter de assumir essa função empreendedora, ele distancia-se cada vez mais de seu papel formativo, porque a educaçáo como um grande negócio e a escola como empresa não têm mais nada a ver com Bildung.

Que novo perfil assume o professor como empreendedor de si mesmo? $\mathrm{Na}$ esteira da governança empresarial que rege o modo de organização escolar, o professor transforma-se em uma espécie de gerente de negócios privados. Isto é, ele trata de seu conhecimento como mercadoria e concebe seu procedimento pedagógico de maneira gerencial. Nesse contexto, o modo de ser professor assume, segundo Jan Masschelein e Maarten Simons (2013), dois grandes traços gerais, profissionalização e flexibilização. No que se refere à profissionalização, em uma de suas variantes, o professor abre mão de seu saber de experiência em nome da especialização, baseada no domínio minucioso de competências que interessam aos princípios e objetivos da governança empresarial. O fato é que o conhecimento especializado fundamentado no domínio de competências enfraquece os aspectos éticos, estéticos e afetivos inerentes ao saber de experiência que sustenta o papel formativo do professor. Desse modo, o caráter espontâneo, criativo e afetuoso do saber de experiência cede lugar ao procedimento instrumental, escrupulosamente calculado, do conhecimento especializado. Em síntese, quando o protótipo do professor expert substitui a figura do professor amateur, perde-se a própria dimensão humanizadora da educação ${ }^{7}$. 
A flexibilização é, como afirmamos, o segundo traço do modo de ser do professor que habita a escola regida pela governança empresarial. Flexibilização é, antes de tudo, um princípio fundamental da empresa neoliberal moderna própria do mundo globalizado, dominado pelo capital financeiro volátil que não conhece mais solo nem pátria. Trata-se, também, de uma nova ordem empresarial que precisa ter a seu favor leis trabalhistas flexíveis que a desonerem de encargos sociais, responsabilizando cada vez mais o trabalhador como empreendedor de si mesmo. É precisamente nesse sentido que a flexibilização exige do trabalhador e, por conseguinte, do próprio professor como trabalhador um monitoramento permanente de si mesmo para que possa atingir suas metas. "É o professor que, como um gerente, exerce um contínuo auto monitoramento do capital adquirido em seu portfólio e dos seus pontos fortes e fracos" (MASSCHELEIN; SIMONS, 2013, p. 147).

Em resumo, o professor profissional e flexível torna-se um professor domado e treinado para executar tarefas e desempenhar funçóes dentro da escola que possam formar mentes dóceis e adestradas pelos dispositivos da governança empresarial. Mas será essa a única alternativa possível para a escola e para o trabalho do professor dentro da sala de aula? Onde pode aparecer o trabalho formativo do professor? $\mathrm{Na}$ sequência, com breve recurso interpretativo ao ideal de mestria estoico, especialmente àquele presente nas Cartas a Lucílio de Sêneca, aventamos a possibilidade de o professor ser de outra maneira, ou seja, adotar outra postura, na qual se destacam seu perfil e seu papel formativos.

\section{A libertas como traço distintivo do mestre antigo}

A figura do mestre na tradição filosófica pedagógica estoica, de maneira especial em Sêneca, é ampla e contém inúmeros problemas, dos quais não podemos tratar aqui. Vamos nos limitar às Cartas a Lucílio, particularmente às cartas 38, 40 e 75, inspirando-nos na interpretação que Foucault faz delas, em $A$ hermenêutica do sujeito (2004), na segunda hora da aula de 10 de março de 1982. Precisamos justificar de modo breve noss referência à interpretação de Foucault, considerando a importância que assume em relação ao nosso problema de tomar o papel formativo do professor como contraponto ao papel profissional e flexível que lhe é imposto pela governança empresarial. Nosso recurso deve-se à preocupação com a formação ética do sujeito, levada adiante por Foucault nos últimos cursos proferidos no Collège de France. Sua preocupação está ancorada na ontologia do presente como crítica da atualidade, entrelaçando-se com a pergunta pela condição do sujeito que faz a própria crítica. É precisamente a condição de um sujeito vivendo em determinado momento histórico, que vê sua subjetividade cada vez mais estilhaçada pelos intensos processos de assujeitamento, que conduz Foucault à investigação da ética antiga, representada de forma 
paradigmática pelo cuidado de si em Sócrates e pelo exercício de si em Sêneca. Em ambos os casos, a formação ética do sujeito póe-se no âmbito da relação tensional inesgotável entre governo de si e governo dos outros, pressupondo a implicação recíproca entre ambos ${ }^{8}$.

O retorno à ética antiga não está de maneira nenhuma desconectada da crítica à condição empreendedora individualista do sujeito neoliberal contemporâneo. Ao contrário, tal retorno significa um experimentum de pensamento, visando fortalecer espiritualmente (intelectualmente) o sujeito contemporâneo para que possa transgredir ou desobedecer ao modo de ser da governança empresarial. O problema repousa nas diferentes formas de assujeitamento do sujeito contemporâneo e nas possibilidades de resistência que ele possui. Contudo podemos objetar a Foucault se ele não estaria, com isso, buscando a solução de um problema atual na resposta oferecida por outros intelectuais a problemas originados em um contexto histórico e social bem diferente do nosso contexto. O próprio Foucault responde a esse questionamento, afirmando que não quer fazer "a história das soluções", mas sim "a genealogia dos problemas, das problematizaçôes" (FOUCAULT, 1994, p. 256, grifo nosso). Ora, é tal problematização que permite a transformação, no sentido de subjetivação ética, do sujeito que investiga as diferentes e antigas práticas de si. Portanto, o aspecto nuclear de tudo isso é o processo de transformação que ocorre com o sujeito que se entrega ao exercício de experiências culturais e intelectuais estranhas e, como é o caso em questão, historicamente distantes do sujeito atual. Foucault pressupóe que o sujeito leitor, ao se ater meditativamente sobre os textos antigos, adquire melhores condiçóes para pensar a atualidade em que vive, na mesma medida em que pensa sobre si mesmo enquanto sujeito que póe sua atualidade em questão. No fundo, o que está subentendido aqui, do ponto de vista da formaçáo humana e, por conseguinte, da educaçáo de novas geraçóes, é a leitura dos textos clássicos como modo de transformação de si mesmo. Em síntese, a leitura, assim como a escrita, torna-se exercício genuíno de reinvenção humana de si mesmo.

Considerando isso, qual é o aspecto significativo da relação entre mestre e discípulo presente nas Cartas a Lucílio, especialmente nas cartas 38, 40 e 75? Por que é indispensável pensarmos na figura do mestre, em seu perfil e no seu papel? O aspecto significativo refere-se à noção de libertas, a qual é, conforme já indicamos, a versão latina da palavra grega paraskeué. Libertas é, desse modo, o núcleo formativo da relaçáo pedagógica entre mestre e discípulo, inserindo-se em um sentido amplo de instruçáo, que visa tomar o ser humano como um todo e não somente em seus aspectos cognitivos voltados para o exercício de determinado ofício. Vejamos, em primeiro lugar, como isso ocorre nas cartas 38 e 40, interpretando-as conjuntamente e, depois, de forma separada, na carta 75 .

A relação formativa entre mestre e discípulo que caracteriza a libertas aparece nas cartas 38 e 40 sob dois aspectos distintos, mas entrelaçados entre 
si. O primeiro aspecto contrapóe-se ao uso artificialmente abundante das palavras, próprio à retórica. Sêneca contrapóe-se a isso afirmando: "De facto, o que é necessário não é a abundância, mas a eficácia das palavras” (SÊNECA, 2014, p. 133) - eficácia refere-se à transparência e simplicidade da fala do mestre. Orientando-se pela libertas, o mestre não pretende seduzir seu discípulo apenas pelo embelezamento de seu discurso, mas sim trazê-lo para junto de si por meio da transparência e da simplicidade. Transparência significa, aqui, a busca pela verdade em contraposição à trapaça e à mentira, pois quem trapaceia e mente perde sua credibilidade e, por isso, não pode ser tomado como mestre. $\mathrm{O}$ trapaceador consegue manter alguém ao seu redor pela força dissimuladora de seu discurso, o qual perverte a relação pedagógica na medida em que quebra a confiança como laço afetivo que une um e outro. Nesse sentido, dito de maneira negativa, a intransparência, que conduz à desconfiança, obstaculiza frontalmente o aspecto formativo inerente à libertas. A simplicidade, por sua vez, apoia-se no propósito ético do mestre de contribuir para que o discípulo aprenda não só o conteúdo de seu ensino, mas o significado existencial de tal conteúdo. Ora, se o núcleo é o interesse ético pelo aprendizado do discípulo, então o mestre, por já ter trilhado o caminho pedregoso da busca pelo saber, procura tornar as coisas mais fáceis para seu discípulo, sem abrir mão, contudo, do sofrimento que implica a relação de conhecimento com as coisas e da exigência de serenidade que tal relação exige. O tornar mais fácil significa aqui o domínio do conteúdo relacionado com o modo de dizê-lo, escolhendo adequadamente as palavras certas e pronunciando-as no momento oportuno. Ou seja, porque o mestre, como veremos logo a seguir, possui uma relação respeitosa com o kairós pedagógico, ele torna-se portador da libertas, pondo em ação sua própria instructio.

O segundo aspecto das cartas 38 e 40, relacionado com o primeiro, diz respeito ao modo de atenção que o mestre presta à condição em que se encontra o discípulo. De que condição se trata e qual é sua importância formativa? Sêneca emprega, nesse contexto, a metáfora da semente para elucidar o trabalho formativo do mestre: cabe a ele lançar pequenas sementes na alma de seu discípulo. Diz Sêneca (2014, p. 134-134): “Devemos distribuí-las [as palavras] como se fossem sementes; ora uma semente, ainda que minúscula, se caí em terra favorável, multiplica as suas energias e alcança, de exígua que era, dimensóes assaz consideráveis”. Para que possa germinar, nascer e tornar-se uma bela planta, a semente precisa ser saudável e cair em solo fértil. Logo, o cuidado do semeador com a semente, onde e quando vai lançá-la e, sobretudo, o modo como vai fazê-lo se tornam questóes decisivas. Ora, é precisamente aí que a analogia da figura do mestre como o semeador ganha sentido formativo, fazendo valer sua condição de educador experimentado. $\mathrm{O}$ mestre precisa preparar bem suas palavras, adequando-as à condição de compreensão do discípulo e, por isso, precisa saber esperar o momento oportuno para pronunciá-las. Esse segundo aspecto da libertas toca em cheio o kairós pedagógico, revelando seu pertencimento mútuo à instructio. 
Como é o kairós pedagógico que torna possível, em última instância, o nexo estreito entre libertas e instructio, precisamos problematizá-lo brevemente.

No âmbito da filosofia, como mostra Foucault (2004, p. 468), estabelece-se oposição, remontada a Aristóteles, entre dois tipos diferentes de arte, que é importante para compreender a dimensão formativa do kairós, a arte conjectural e a arte metódica. Enquanto a arte metódica se refere ao procedimento único que busca a verdade por meio de regras fixas e determinadas previamente, a arte conjectural baseia-se em argumentos verossímeis que dispensam o procedimento único, retilíneo e fixo. Desse modo, o rigor metódico cede lugar ao improviso criativo, como procedimento capaz de apanhar a indeterminação e plasticidade da ação humana ${ }^{9}$. Ora, esse procedimento improvisado e flexível da arte conjectural nutre-se do kairós, transformando-se ela própria em arte formativa. Em que sentido? Pela observância cuidadosa e atenta das circunstâncias e do momento oportuno, que caracterizam o modo de agir pedagógico formativo. Sendo assim, o kairós não pode ser compreendido por meio do procedimento único simplesmente, porque ele é a síntese fugidia que se renova a cada momento e situação, influenciado pela conjugação não previsível de vários fatores. É isso, então, que constitui o aspecto formativo do kairós, traduzindo-se na postura adequada do mestre em relação ao discípulo, que o faz saber escolher, com base em sua longa experiência formativa, o melhor momento para intervir ou deixar acontecer. O mestre só consegue escolher esse momento porque, além de conhecer bem as circunstâncias que envolvem a relação pedagógica, também leva a sério a condição cultural de seu discípulo. De outra parte, o kairós pedagógico remete-se à noçáo de limite, que interfere diretamente na ação do mestre, pois ele sabe, por intermédio de suas longas e sofridas experiências pedagógicas, que não é senhor de todas as circunstâncias e, por isso, não possui pleno domínio do momento oportuno. Ou seja, o mestre sabe perfeitamente que não pode dominar por completo nem de maneira definitiva todos os fatores que interferem na escolha de quando agir ${ }^{10}$. A impossibilidade da determinação absoluta desse momento conduz o mestre à postura de humildade e, com isso, ao reconhecimento da própria dimensão imprevisível e indeterminada da experiência formativa humana.

Voltemo-nos agora para o conteúdo da carta 75 . Nela, Sêneca preserva à libertas o sentido originário grego do falar franco, acentuando sua dimensão formativa. Sêneca define esse falar da seguinte maneira: "Nosso objetivo último deve ser este: dizer o que sentimos, sentir o que dizemos, isto é, pormos a nossa vida de acordo com as nossas palavras" (SÊNECA, 2014, p. 306). Se o alvo do falar franco é o discípulo, o que almeja essa veracidade do mestre? Ela visa, como adverte Sêneca, não só ao ingenium, a inteligência engenhosa, mas o animi negotium (negócio da alma), ou seja, o modo especial de governo da alma, que sustenta a própria ideia ampla de formação humana. Desse modo, a libertas possui, antes de tudo, o sentido ético voltado à formaçáo de todos os aspectos constituintes da conduta 
do discípulo e que orientam seu modo de ser e viver no mundo. Isso não significa dizer que o animi negotium nega ou ignora as capacidades cognitivas indispensáveis ao exercício de ofícios especializados. Antes disso, ele mostra que o pensar engenhoso precisa estar ancorado no questionamento sobre o que constitui o próprio negócio da alma. Portanto, o que está em jogo aqui - sendo precisamente isso que interessa a Sêneca - é o efeito que esse dizer provoca na condição do discípulo, integralmente, levando-o a se questionar sobre o sentido de sua vida e sobre o lugar que ocupa na ordem das coisas. O que interessa, em primeiro lugar, ao falar franco não é simplesmente a atitude cognoscitiva de conhecimento, mas sim o modo de ação e, por conseguinte, a postura que se adota diante de si mesmo, dos outros e das coisas como um todo. Sendo assim, o efeito formativo do falar franco mostra-se melhor quando há a oportunidade de exercitá-lo. Em resumo, é na ação, no exercício, que tal falar se mostra. Como afirma Foucault (2004, p. 489): "É na experiência que se medirá a eficácia, a utilidade da palavra ouvida que foi transmitida pela parresia [libertas, acréscimo do autor".

Com essa exposição, alcançamos o aspecto nuclear da libertas como busca constante da coerência entre dizer e fazer, entre falar e agir. Desse modo, o franco falar exige, para que se torne de fato formativo, a conduta coerente do mestre, mais precisamente de seu testemunho em ato, isto é, de seu compromisso discursivo com a veracidade de sua ação. É, no fundo, o exemplum do mestre que fortalece seu próprio falar franco, movendo o discípulo na direção da formação ética de si mesmo. Ao ouvir silenciosamente, de maneira compenetrada, as palavras francas do mestre, o discípulo compreende que a partir de então já não pode mais falar qualquer coisa, dizendo simplesmente o que lhe vem à mente, pois é conduzido a meditar detidamente sobre suas próprias palavras. Ao mesmo tempo, ao experienciar em sua própria ação o exemplo do mestre, também já não pode mais agir de qualquer modo, seguindo tão somente o impulso de suas inclinações ou deixando-se mover pelos ventos fortes que o pressionam do exterior. Ao contrário disso, precisa pensar antes de agir e voltar novamente a refletir sobre a ação realizada. É a meditação demorada sobre suas próprias palavras e açóes que conduz o discípulo a se interessar de maneira ética por si mesmo e a lapidar sua relação com o mundo. $\mathrm{O}$ mesmo interesse ético que o mestre mostra no início por seu discípulo se traduz no próprio interesse ético que o discípulo passa a ter por si mesmo e pelos outros. Ora, é essa meditação demorada sobre o franco falar e o agir coerente, tanto do mestre como do discípulo, que constitui o aspecto vinculante entre instructio e libertas e que, portanto, está na base da formação ética do sujeito.

\section{A ênfase no trabalho formativo do professor}

Empreendemos até aqui duplo movimento reflexivo. Investigamos, no primeiro movimento, diferentes formas de reducionismo da educação con- 
temporânea, provocadas pela invasão da governança empresarial neoliberal nas instituiçóes de ensino, focando no empobrecimento da experiência docente. Chegamos ao resultado de que, uma vez reduzida aos critérios do gerenciamento empresarial da competição, da eficiência e da lucratividade, a educação se transforma em mercadoria, perdendo cada vez mais sua dimensáo formativa. No segundo movimento reflexivo, reconstruímos, orientando-nos pelo intuito de enfrentar as consequências destrutivas que o gerenciamento empresarial neoliberal provoca à educação, alguns traços do perfil do mestre que emergem da noção latina da instructio, concentrando-nos no ideal da libertas como núcleo da relação formativa entre mestre e discípulo, ou seja, entre educador e educando.

Dessa reconstrução, procuramos extrair agora, como breve conclusão, alguns argumentos favoráveis ao papel formativo do professor em contraste com o perfil traçado pela educação neoliberal, que não só desfigura o núcleo ético e político da profissão docente, como embrutece assustadoramente a condição humana e social contemporânea. Não se trata aqui, como já nos precavemos, de querer simplesmente transpor a figura do mestre antigo para o professor em tempos de neoliberalismo, pois as diferenças específicas entre os dois contextos históricos tornam problemático tal propósito. Ademais, a complexidade da ação do professor contemporâneo, que além de ocorrer mediante condiçóes de trabalho crescentemente precarizadas e voltar-se para o atendimento de um número cada vez maior de alunos, quer sejam presenciais, quer sejam a distância, difere de modo substancial da ação do mestre antigo, que, no caso especialmente de Sêneca, está dirigida somente a um discípulo. Essas consideraçôes impóem, então, cautela ao buscar estabelecer analogias entre o mestre antigo e o professor contemporâneo. Considerando isso, gostaríamos de reter três aspectos do ideal formativo do mestre baseado na libertas que nos auxiliam a problematizar o papel formativo do professor contemporâneo, tomando tal papel formativo como contraponto crítico ao perfil embrutecedor imposto pela educação neoliberal ao trabalho profissional do professor.

O primeiro aspecto refere-se à ampla natureza ética da educação e, de maneira específica, da condição formativa do trabalho pedagógico do professor. O sentido da ética está profundamente relacionado ao questionamento sobre formas de ser e viver do ser humano, ou seja, sobre o sentido e a finalidade de sua existência e de sua relaçáo com os outros e com o mundo. Sendo assim, a ética tem a ver com o modo de vida exigente que acontece na ação, dinamizada por meio de diferentes exercícios ou práticas de si que visam lapidar a condição humana como se lapida uma obra de arte. Nesse sentido, a educação, antes de ser uma técnica voltada exclusivamente para o desenvolvimento de competências e habilidades específicas, dirigidas à satisfação das demandas imediatas do mercado de trabalho, é uma arte no sentido do cultivo amplo e permanente do ser huma- 
no, ou seja, do cultivo de todas as suas capacidades. O professor é, pensando em termos metafóricos, como o artífice ou artesão que lapida paciente e amorosamente sua obra de arte, sem impor a ela, de maneira autoritária ou agressiva, uma forma, mas sim contribuindo para que tal forma brote das capacidades do próprio ser em formação. Somente por ter buscado lapidar-se a si mesmo, tomando sua existência como uma obra de arte e ter feito a experiência dos sofrimentos e das exigências que isso significa é que o professor constrói a abertura indispensável para poder tomar a existência do próprio aluno como uma obra de arte. Ao compreender-se a si mesmo como um artífice que se deixa orientar abertamente por experiências plurais de vida, o professor torna-se resistente à coação mercadológica externa que procura reduzi-lo exclusivamente ao sujeito empreendedor dos modos neoliberais de ação. Ao conceber sua ação docente na forma de lapidação cuidadosa de uma obra de arte, o professor insurge-se contra as diferentes formas de agressão selvagem que o modelo de gerenciamento empresarial impóe à educaçáo escolar, não aceitando a modelagem reducionista inerente ao ensino por competências e habilidades.

O segundo aspecto, relacionado ao primeiro, diz respeito ao kairós como aspecto constituinte da relação formativa entre professor e aluno. Se o aspecto formativo do kairós repousa no respeito do mestre pelas condiçóes culturais e afetivas iniciais do discípulo, então tal aspecto também exige do professor a compreensão da condição educativa inicial de seu aluno. Tal compreensão é ética antes de ser cognitiva, pois exige do professor a postura de abertura para levar criticamente em consideraçáo o ponto de vista do aluno. A retomada do kairós formativo também cumpre hoje em dia a finalidade de criticar a fantástica aceleração do tempo que, potencializada pelo uso obsessivo dos dispositivos digitais, toma conta das formas de vida contemporâneas, colonizando a própria relação pedagógica entre professor e aluno. Portanto, encontrar o momento oportuno para intervir ou deixar acontecer torna-se mais exigente ao professor, porque ele, assim como seus alunos, também é movido pela pressa e dispersão da sociedade digital contemporânea. Por isso, torna-se ainda mais atual, nesse contexto, a recuperação da dimensão formativa do kairós, compreendida como escolha do melhor momento para agir. A atitude de serenidade e de pensamento meditativo que tal escolha exige se torna, ao mesmo tempo, um antídoto à ausência de concentração, que caracteriza a dispersão do sujeito contemporâneo e de seus processos pedagógicos. De outra parte, a paciência, que caracteriza o respeito pelo momento oportuno da ação formativa, contrapóe-se normativamente à pressa educacional neoliberal, que aligeira de maneira extraordinária o tempo de formação do aluno para vê-lo atuando como profissional o mais rápido possível no mercado de trabalho. Deixando-se influenciar espiritualmente pelo kairós formativo, o professor rebela-se contra a pressa agressiva que a educação neoliberal quer impor aos processos formativos escolares. Descortina ao aluno outros saberes e 
modos culturais de vida que o permitem lapidar sua vida como se estivesse lapidando uma obra de arte.

Por fim, o último aspecto relaciona-se ao falar franco da libertas, que, como busca pela coerência entre falar e agir, visa ao animi negotium. Aqui se destaca o exemplum do professor como referência paradigmática de uma forma de viver que influência profundamente as capacidades cognitivas, éticas e afetivas do educando. Isso tem a ver com o fato, acentuado pela boa tradição das teorias pedagógicas, desde a Antiguidade até os nossos dias, de que a educaçâo é, antes de tudo, uma relação afetiva entre educador e educando, com base na qual se constrói todo o edifício pedagógico. Sendo assim, o exemplum refere-se neste artigo, do ponto de vista normativo, ao cuidado respeitoso do professor consigo mesmo, ao seu compromisso com a veracidade e, por conseguinte, à busca permanente pela coerência entre seu modo de falar e agir. Esse exemplum, como pano de fundo existencial de dimensão ética afetiva, torna-se a principal força movente que ativa as capacidades do aluno. Em síntese, o exemplum ético formativo move os interesses do aluno na direção de sua responsabilidade pelo mundo, criando condiçôes intelectuais para que reflita criticamente sobre os princípios que sustentam os modos neoliberais de vida e que dificultam a construção cooperativa e solidária do espaço humano e social do viver junto.

Concluindo, com as consideraçóes expostas pensamos ter deixado claro o quanto o perfil traçado ao professor pela educação neoliberal não só impossibilita seu papel formativo como, principalmente, embrutece a vida humana como um todo. De outra parte, insistimos na possibilidade de que tal papel formativo possa ser retomado, como exemplo, à base da problematização do ideal da libertas do mestre antigo. Esse trabalho intelectual de diálogo investigativo com a tradição, que também é parte importante do trabalho intelectual do professor, amplia de maneira significativa, como vimos, sua capacidade formativa, transformando-o em agente crítico da educação humanizadora. Portanto, a postura intelectual crítica alicerçada eticamente no espírito de cooperação solidária se torna contribuição social indispensável do professor, caracterizando seu incansável trabalho de formação das novas geraçóes, revertendo-se tudo isso na voz ativa contra o empobrecimento espiritual crescente provocado pela educaçáo neoliberal.

\section{Notas}

1. Sobre o mal-estar docente, ver Esteve (1999) e Reis (2006).

2. Sobre o pensamento de Kant na perspectiva educacional, ver Dalbosco (2011); sobre Herbart, ver Dalbosco (2018b; 2018d).

3. Referimo-nos aqui à Escola sem Partido. Para uma visão crítica desse movimento, sua origem e sua finalidade, ver a coletânea organizada por Frigotto (2017). 
4. Para o tema da condição do sujeito contemporâneo na perspectiva da psicanálise, ver, especialmente, Birman (2014), Ehrenberg (2008) e Lebrun (2008). Em relaçáo à posição do sujeito diante das massas digitais, ver Dunker (2019).

5. O tema do reconhecimento social é central para pensar o problema da cooperação solidária. Para uma reflexão desse tema na filosofia social de Rousseau e Honneth, ver Dalbosco (2016, p. 248-266; 2018c, p. 456-474).

6. Para uma visão resumida do modo como a educação alemã assumiu após o Acordo de Bolonha a governança empresarial, distanciando-se mais e mais da tradição da Bildung, ver o estudo de Lenzen (2014). Para uma reflexão sobre o renascimento ou despedida da Bildung, ver a coletânea organizada por Dalbosco, Mühl e Flickinger (2019), especialmente os ensaios de Goergen (2019, p. 1.534) e Dalbosco (2019, p. 35-64).

7. O tema da profissionalização do professor, quando visto pela perspectiva crítica e não pela ótica do gerenciamento empresarial, assume sentido diferente, tornando-se ferramenta indispensável para que o professor possa desempenhar seu papel formativo. Sobre isso, ver Paro (2018).

8. Tal implicação recíproca fica clara especialmente na primeira parte de $A$ hermenêutica do sujeito, na qual Foucault (2004) interpreta de forma detalhada Alcibiades, de Platão, assinalando o quanto a vontade de governar os outros, manifestada a princípio por Alcibíades, depende da capacidade de bem governar a si mesmo.

9. A plasticidade, assim como perfectibilidade e multiplicidade do interesse, é um conceito-chave de algumas teorias educacionais clássicas, influenciando decisivamente na própria noção de educação democrática. Sobre esse tema, ver Dalbosco (2018a).

10. Pierre Aubenque (2003, p. 156-171) investiga a origem aristotélica da noção de kairós, mostrando como ela é duplamente constituída, como momento oportuno e como limite. Contudo o estoicismo, principalmente de Sêneca, atribui ao kairós sentido formativo claro, quando o pensa como aspecto constituinte da relação entre mestre e discípulo.

\section{Referências}

AUBENQUE, P. A prudência em Aristóteles. São Paulo: Discurso, 2003.

BIESTA, G. Para além da aprendizagem: educação democrática para um futuro humano. Belo Horizonte: Autêntica, 2013.

BIESTA, G. The Rediscovery of Teaching. Nova York: Routledge, 2017.

BIRMAN, J. O sujeito na contemporaneidade. Rio de Janeiro: Civilização Brasileira, 2014. 
DALBOSCO, C. A. Condição humana e educabilidade: um problema nuclear das teorias educacionais clássicas. Revista Brasileira de História da Educaçáo, v. 18, n. 48, p. 1-20, 2018a. http://dx.doi.org/10.4025/rbhe.v18.2018.e013

DALBOSCO, C. A. Condição infantil e autoridade amorosa em Johann Friedrich Herbart. Educaçáo e Realidade, Porto Alegre, v. 43, n. 3, p. 1131-1148, 2018b. http:// dx.doi.org/10.1590/2175-623674872

DALBOSCO, C. A. Conditio humana und tugendhafte Willensbildung: Untiefen der Anerkennung bei Rousseau und Honneth. Vierteljahrsschrift für wissenschaftliche Pädagogik, Heft, v. 94, p. 456-474, 2018c. https://doi.org/10.30965/25890581$\underline{09403008}$

DALBOSCO, C. A. Kant e a Educação. Belo Horizonte: Autêntica, 2011.

DALBOSCO, C. A. Metamorfoses do conceito de formação: da teleologia fixa ao campo de força. In: DALBOSCO, C. A.; MÜHL, E. H.; FLICKINGER, H. G. (orgs.). Formaçáo humana (Bildung): despedida ou renascimento? São Paulo: Cortez, 2019. p. 35-64.

DALBOSCO, C. A. Uma leitura não-tradicional de Johann Friedrich Herbart: autogoverno pedagógico e posição ativa do educando. Educação e Pesquisa, São Paulo, v. 44, p. 1-18, 2018d. http://dx.doi.org/10.1590/s1678-4634201844182622

DARDOT, P.; LAVAL, C. A nova razáo do mundo. Ensaio sobre a sociedade neoliberal. São Paulo: Boitempo, 2016.

DUNKER, C. I. L. Psicologia das massas digitais e análise do sujeito democrático. In: ABRANCHES, S. et al. Democracia em risco? 22 ensaios sobre o Brasil hoje. São Paulo: Companhia das Letras, 2019. p. 116-135.

EHRENBERG, A. Das erschöpfte Selbst. Depression und Gesellschaft in der Gegenwart. Frankfurt: Suhrkamp, 2008.

ESTEVE, J. M. O mal-estar docente: a sala de aula e a saúde dos professores. Bauru: Edusc, 1999.

FOUCAULT, M. A hermenêutica do sujeito. São Paulo: Martins Fontes, 2004.

FOUCAULT, M. Nascimento da biopolítica. São Paulo: Martins Fontes, 2008.

FOUCAULT, M. Sobre a genealogia da ética. In: DREYFUS, H. L.; RABINOV, P. Uma trajetória filosófica. Para além do estruturalismo e da hermenêutica. Rio de Janeiro: Forense Universitária, 1994. p. 253-278.

FRIGOTTO, G. (org.). Escola "sem” partido: esfinge que ameaça a educação e a sociedade brasileira. Rio de Janeiro: Editora da UERJ, 2017.

GOERGEN, P. L. Bildung ontem e hoje: restrições e perspectivas. In: DALBOSCO, C. A.; MÜHL, E. H.; FLICKINGER, H. G. (orgs.). Formação humana (Bildung): despedida ou renascimento? São Paulo: Cortez, 2019. p. 15-34.

LAVAL, C. A Escola náo é uma empresa. O neoliberalismo em ataque ao ensino público. Londrina: Planta, 2004. 
LEBRUN, J. P. A perversão comum. Rio de Janeiro: Companhia Freud, 2008.

LENZEN, D. Bildung statt Bologna! Berlim: Ullstein Buchverlag GmbH, 2014.

MASSCHELEIN, J.; SIMONS, Maarten. Em defesa da escola. Uma questão pública. Belo Horizonte: Autêntica, 2013.

PARO, V. H. Professor: artesão ou operário? São Paulo: Cortez, 2018.

REIS, J. F. B. E. et al. Docência e exaustão emocional. Educação e Sociedade, Campinas, v. 27, n. 94, p. 229-253, jan./abr. 2006. http://dx.doi.org/10.1590/S0101$\underline{73302006000100011}$

SÊNECA, L. A. Cartas a Lucílio. Lisboa: Fundação Calouste Gulbenkian, 2014.

VINCENT, G.; LAHIRE, B.; THIN, D. Sobre a história e a teoria da forma escolar. Educaçáo em Revista, Belo Horizonte, n. 33, p. 7-47, 2001.

\section{SOBRE O AUTOR}

Claudio Almir Dalbosco é doutor em filosofia pela Universität Kassel (Alemanha, 2001) e pós-doutorado pelo Núcleo Direito e Democracia (NDD) do CEBRAP (2013). É Bolsista Produtividade em Pesquisa nível 1D do CNPq. Possui diferentes publicaçóes nacionais e internacionais, com destaque para o livro Condição Humana e Educação do amor próprio em Jean-Jacques Rousseau, publicado em 2016 pelas Ediçóes Loyola.

Recebido em 22 de fevereiro de 2019.

Aceito em 12 de junho do 2019. 